IFéher, D., 1933. Untersuchungen über die Mikrobiologie des Waldbodens. Berlin: Julius Springer.

2Savile, D. B. O., 1959. The botany of Somerset Island, District of Franklin. Can. J. Bot. 37:959-1002.

3Kelsall, J. P., 1959. A poisonous fungus in the Northwest Territories. Can. Field. Nat. 73:130.

4Favre, J., 1955. Les champignons supérieurs de la zone alpine du Parc National Suisse. Part 5, N.S. 33:1-212.

5Williamson, E. S. L., 1957. Ecological distribution of birds in the Napaskiak area of the Kaskokwim River Delta, Alaska. The Condor 59:317-338.

6Cash, Edith, 1953. Fungi of Alaska. Pl. Dis. Reptr., Suppl., 219:1-70.

7Cooke, W. B., and D. B. Lawrence, 1959. Soil mold fungi isolated from recently glaciated soils in Southeastern Alaska. Jour. Ecol. 47:529-549.

8Sprague, R., 1955. Check list of the fungi of the Glacier Bay National Monument, Alaska. Washington State College Research Studies, Pullman, 23:202-224.

9Sprague, R., and D. B. Lawrence, 1959, 1960. The fungi on deglaciated terrain of known age. Washington State University Research Studies, Pullman. 27:111-128, 224-229; 28: (in press).
Application for the position of Executive Director of the Boreal Institute of the University of Alberta.

The Boreal Institute invites applications for the above position.

The Executive Director will be a fulltime appointee who will aid the Directorate in planning the activities of the Institute, implement its decisions, administer its daily operations, solicit funds for its advancement and publicize its activities and accomplishments.

Applicants must be interested in the North, have administrative ability, ability to deal with the public and be fluent in written and spoken English. They should be willing and able to travel in the North and have some northern experience.

Applications must include a complete account of experience and educational background, references, other pertinent data, and a recent photograph.

The appointment will be effective April 1, 1961. Salary will depend upon qualifications. Applications should reach the Boreal Institute, University of Alberta, Edmonton, Alberta, Canada, before February 1, 1961. They will be held in confidence if desired.

\title{
INSTITUTE NEWS
}

The Arctic Institute Devon Island Expedition 1960.

The Arctic Institute of North America, having decided that scientific research in the Arctic could be significantly advanced by establishing permanent base facilities at certain key localities and conducting long term, detailed, integrated observations in several scientific fields, initiated the Devon Island Expedition 1960-1963, the objectives of which are:

(1) A study of the relationships between the marine environment (Jones
Sound), the Devon Island Ice Cap, and the atmosphere, with special regard to heat budget, energy flow, and moisture transfer.

(2) A detailed investigation of the oceanography and marine biology of Jones Sound.

(3) A detailed investigation of the archaeology, biology, and geology of Devon Island, together with other studies that may provide auxiliary information for objective (1).

The main purpose of the 1960 expedition was to establish facilities and cache 
supplies to support the scientific program beginning in 1961 . The party consisted of the following: S. Apollonio, leader; V. D. Boyd, master mechanic; B. D. Clarke, tractor specialist; C. R. Harington, naturalist and general assistant; G. R. Lowther, archaeologist; R. S. McCall, archaeological assistant; D. R. Oliver, zoologist and general assistant; G. E. Stewart, Weasel specialist.

The party left Quebec City on July 31 on board C.M.S. d'Iberville and arrived off Cape Skogn, Devon Island on August 20. By August 24 a camp consisting of three prefabricated Jamesway buildings and stores for twenty people for 5 months was installed at $75^{\circ} 42^{\prime} \mathrm{N}$. $84^{\circ} 26^{\prime} \mathrm{W}$.

An 18-mile tractor route to the edge of the ice cap was then laid out and 6 tons of ice cap station supplies were hauled to the top of a 1000-foot plateau at the beginning of that route. The top of the plateau, the only practicable route to the ice cap, was found to be thawed to such an extent that the tractors became mired to the axles. It was decided to cache the supplies at the edge of the plateau and to establish the ice cap station in the spring of 1961, when the ground will be frozen.

On September 6, Apollonio, Harington, and Stewart examined the ice cap margin and found that it is readily accessible to tracked vehicles. The base camp, the power boat, the two diesel tractors, and the two Weasels were then secured for the winter.

The party were picked up by helicopter of the U.S. icebreaker Westwind and taken to Thule, Greenland, from where they flew on a USAF MATS flight to New Jersey and returned to Montreal on September 16.

The archaeologists located two previously unknown sites. The first, in the vicinity of the base camp, includes four or five houses, three temporary houses, and several caches. It is probably a late Thule site.

The second site is located near the western tip of Cape Sparbo and has been tentatively named the "Inapok" site. It was studied by Lowther, McCall, and Oliver from August 26 to August
31 and includes 9 houses, tent rings, and a number of other structures. There are undoubtedly both Dorset and Thule, and perhaps pre-Dorset elements in the site. The entire site is well preserved and has yielded about 90 artifacts including Dorset blades, microblade points, burins, microburins, burin spalls, knives, and end blades.

Oliver continued his study of arctic chironomids and other aquatic insects by extensive collecting at Resolute and on Devon Island. Harington measured over 60 musk ox skulls and made a comprehensive plant collection.

The Devon Island Station will be reoccupied in late April 1961, at which time the ice cap station will be established. Studies in meteorology, glaciology, oceanography, marine biology, and geology will then begin. The archaeological work will continue with a detailed excavation of the "Inapok" site and further reconnaissance of the island.

\section{Spencer Apollonio}

\section{Ellesmere Island Ice Shelf Project 1960}

During 1960 the Arctic Institute of North America continued the studies in Ellesmere Island that were begun in 1959 under contract to the Terrestrial Sciences Laboratory of Air Force Cambridge Research Center of the U.S. Air Force. The Defence Research Board of Canada had an observer with the party, and the Institute cooperated in the field with groups from Dartmouth College, Hanover, N.H. and the U.S. Naval Civil Engineering Laboratory. Twenty-three persons were actively engaged in field work between April 26 and September 24,1960 , but only seven men remained on the Ice Shelf throughout the season - Dr. Lister, R. B. Sagar, R. L. Lenton, F. Layman, J. Mulholm, I. Spokas, and R. Grant. Dr. G. Rigsby was in charge of the overall program for the Institute, and Dr. H. F. Lister was the Field Leader. Personnel and supplies were airlifted by a turbo jet C130 Hercules under the command of Captain G. Khourie.

The main program was an evaluation of the mass balance of the Ward Hunt Ice Shelf and Ice Rise. A survey line from the mainland to the edge of the Ice 